\title{
Enforcers Beyond Borders: \\ Transnational NGOs and the Enforcement of International Law
}

Accepted for publication in Perspectives on Politics, July 22, 2019.

Mette Eilstrup-Sangiovanni

Dept. of Politics and International Studies

University of Cambridge

mer29@cam.ac.uk

J.C. Sharman

Dept. of Politics and International Studies

University of Cambridge

jcs207@cam.ac.uk 


\begin{abstract}
Scholars have studied international NGOs as advocates and service providers, but have neglected their importance in autonomously enforcing international law. This paper has two basic aims: first establish the nature and significance of transnational NGO enforcement, and second to explore the factors behind its rise. NGO enforcement comprises a spectrum of practices, from indirect (e.g., monitoring and investigation), to direct enforcement (e.g., prosecution and interdiction). We explain NGO enforcement by an increased demand for the enforcement of international law, and factors that have lowered the cost of supply for non-state enforcement. The former reflects the growing gap between the increased legalization of international politics and states' limited enforcement capacity. On the supply side, the diffusion of new technologies and greater access to new legal remedies facilitate increased non-state enforcement. We evidence these claims via case studies from the environmental and anticorruption sectors.
\end{abstract}




\section{Enforcers Beyond Borders:}

\section{Transnational NGOs and the Enforcement of International Law}

Enforcement of international laws is conventionally considered the responsibility of the state. Yet NGOs have assumed an important and growing role in various forms of cross-border law enforcement. Their activities range from patrolling, surveillance and investigation, to confiscation or destruction of illegal equipment and proceeds of crime, and litigation and prosecution before domestic and international courts. Such actions are carried out autonomously, sometimes in parallel with state law enforcement agencies, but often in lieu of state led enforcement, or even in the teeth of state opposition. How should we conceptualize transnational law enforcement by NGOs? What factors prompt such enforcement? What are the broader implications for the international legal order?

A burgeoning literature in International Relations (IR) has focused on how transnational actors use information to raise public awareness and pressure states to change policies, or on how NGOs may be contracted by states to deliver services like education and humanitarian aid, or to monitor compliance with international treaties. More recently, scholars have considered how NGOs can be "orchestrated" as intermediaries by inter-governmental organizations (IGOs) in pursuit of IGO governance goals (e.g., Tallberg 2015; Abbott and Snidal 2009; Abbott, LeviFaur and Snidal 2017). Few scholars, however, have considered an autonomous role for NGOs in enforcing international laws. ${ }^{1}$ This article aims to fill this gap in demonstrating how NGOs decentralize and pluralize international law enforcement.

${ }^{1}$ Exceptions include Moffa 2012; Eilstrup-Sangiovanni and Phelps-Bondaroff 2014. See also Eilstrup-Sangiovanni 2018. 
We have two main goals. The first is descriptive and conceptual. We offer a novel understanding of "transnational enforcement" which highlights the role of NGOs as direct contributors to all stages of the global policy cycle: from agenda-setting and policyformulation, to implementation and enforcement. In doing so, we provide examples evidencing a spectrum of NGO-led enforcement - from indirect to direct - and contrast these to more traditional NGO advocacy roles.

Transnational enforcement is a new concept that describes a mix of relatively long-established forms of NGO behavior, but also some new practices, like interdiction and confiscation of illegal equipment. Many of the tactics that fall toward the indirect end of the enforcement spectrum — such as surveillance and investigation — have long been practiced by NGOs and written about by scholars, especially in the area of human rights. However, their nature and significance have often been mischaracterized as forms of advocacy designed to shame lawbreakers or highlight the plight of victims. We argue for the need to see these established NGO practices in a new way. Autonomous monitoring, investigation and prosecution by NGOs as part of a strategy to hold violators of international law to account are better conceptualized as a form of enforcement than as advocacy. Too often, IR scholars have been looking at NGO enforcement without recognizing it as such. A formalistic, state-centric understanding of the concept based on the presumption that an act aimed to compel abidance to the law only counts as enforcement if carried by a state authority, thereby making a tautology of the assumption that states hold a monopoly on law enforcement. By offering a taxonomy of NGO enforcement we thereby provide a corrective to state-centric views which restrict our understanding of the roles of non-state actors in global governance.

Our second goal is to offer an explanation of the drivers of transnational NGO enforcement. 
We point to two main factors affecting the demand for and supply of enforcement beyond the state. First, the past few decades have seen a rapid diffusion of laws criminalizing certain transnational activities such as money laundering and trafficking in weapons, people and endangered species (Simmons et al. 2018: 249, McCormick 2011: 92; Mitchell 2017), which has generated a growing demand for enforcement at both the international and domestic level. Limited state capacity has in turn meant that this demand for enforcement has often gone unfulfilled by governments, especially in areas like the environment and corruption where crimes often cross borders. The resulting deficit of transnational enforcement has created a gap for NGOs to fill. On the supply side, we show that new surveillance and data-gathering technologies allow NGOs to conduct monitoring and investigation more extensively, effectively, and cheaply than ever before. Finally, changes to procedural laws in many jurisdictions have widened non-state actors' access to international and domestic courts. These changes have put new civil and criminal remedies in the hands of transnational activists, leading to an increase in litigation, initially in the realm of human rights (as documented in previous scholarship; see Michel and Sikkink 2013; Dancy and Michel 2016; Gallagher 2017; Michel 2018), but now also in other areas of global governance.

The empirical part of the article charts the operation of transnational enforcement of laws governing international environmental conservation and countering corruption. These cases support our definition of the concept of transnational enforcement, illustrate the spectrum of transnational enforcement activities, and highlight the legal and technological dynamics propelling NGOs into this role. This evidence illustrates both the rise of new enforcement practices and the spread of long-standing practices (such as litigation) from human rights to environmental and anti-corruption policy. In probing the plausibility of our explanatory framework, the paper is an exercise in theory construction rather than systematic theory testing, 
or in Gerring's terms, exploratory rather than confirmatory research (Gerring 2017, 20; see also Mahoney 2015, 201).

The final section considers the implications of non-state enforcement for the international legal order. The global NGO community has important resources to bring to law enforcement, especially with regards to transnational crimes. At the same time, NGO enforcement raises thorny normative questions about legitimacy, due process, and political accountability. In a domestic setting, unauthorized law enforcement by private actors (that is, "vigilantism") is generally shunned. However, the international domain has several features that distinguishes it from a domestic environment, including a dearth of stated-led law enforcement, and a general reliance on decentralized rather than centralized enforcement. In this setting, non-state enforcement may present a cost-effective way to address persistent enforcement deficits (Dai 2002; Tallberg 2015).

Our analysis has fundamental implications for the study of global governance. Recognizing the role of NGOs in international enforcement accentuates a more general trend toward the pluralization of what were previously seen as essential state prerogatives (Avant et al. 2010; Sending and Neumann 2006; Buthe and Mattli 2011). Just as scholarship on global governance has established the notion that many governance functions are supplied by actors other than governments, we argue for the idea of pluralized and decentralized transnational enforcement beyond the state. Our argument thus helps to displace a narrow state-centrism that threatens to restrict and warp our understanding of world politics.

That international rule enforcement is increasingly pluralized beyond the state is not news, as the large literature on private military and security companies attests (Singer 2003; Avant 2005; 
Krahmann 2010; Abrahamsen and Williams 2011). Aside from the profit motive, however, there are key differences between these private corporations and NGO enforcers. The former are contracted by governments or private corporations to provide a specific service, the latter enforce international law in a legal context created by states, but without being seconded or controlled by governments (Brenner 2007). While some IGOs wield their own enforcement powers (e.g., the UN Security Council and International Criminal Court), conceptually and empirically the idea of such "delegated enforcement" by clubs of states is less novel than that of non-state enforcement.

\section{NGOs and Global Governance}

Since the 1990s, a growing literature in IR has explored the role of non-governmental actors in global governance. The bulk of this literature examines how NGOs use information to promote new norms and shape international law and policy (inter alia, Keck and Sikkink 1998; Price 2003; Khagram et al. 2002; Bob 2005). NGOs contribute to three stages of global policymaking. At the pre-negotiation or agenda-setting stage, NGOs promote new norms, and challenge states to translate these into policies - often via their incorporation into international law (Clark 2001; Finnemore and Sikkink 1998; Keck and Sikkink 1998; Khaghram et al. 2002; Tallberg et al. 2018). At the policy-formulation stage, NGOs offer input into international negotiations and provide technical and policy-relevant information to states and IGOs. Once norms are translated into law, NGOs may assist with policy implementation by assuming direct operational functions (for example, delivering education or health care services, or undertaking environmental conservation programs) (Breitmeier and Rittberger 2000, 142-7; Betsill 2014, 196; Gemmill and Bamidele-Izu 2002). Services rendered by NGOs may also include monitoring, analysis, or technical support aimed at increasing the compliance capacity of 
states. For example, Dai $(2002,405)$ finds that states often rely on NGOs to monitor environmental regimes. Tallberg (2015) examines how IGOs "orchestrate" NGOs for similar purposes. Finally, NGOs are often seen to encourage compliance through persuasion, or by naming and shaming transgressors (Keck and Sikkink 1998, 17; Price 2003, 595; HafnerBurton 2008; Murdie and Davis 2012).

Thus as conceived in extant literature, the primary roles of NGOs are to call attention to problems, to instigate new norms, and to put pressure on states to translate these into law. NGOs may assist states in formulating new legislation and in being contracted to provide delegated implementation functions. Yet, ultimately, they defer to states to ensure that international laws are enforced. As Finnemore and Sikkink (1998) argue, transnational actors are "rarely able to 'coerce' agreement to a norm-they must persuade" (see also Khagram et. al 2002, 11; Stroup and Wong 2017, 9).

Nonetheless, some NGOs have challenged this prevailing division of labor by taking international law enforcement into their own hands. Unlike NGOs focused on advocacy, NGOs engaged in transnational enforcement do not address global problems by promoting new norms and lobbying for these to be enshrined in international agreements. Nor are they contracted or orchestrated by states to assist in policy implementation. Instead, they seek to compel compliance through calculated and autonomous engagement with formal law enforcement agencies and the legal system. As Wietse van de Werf, founder of the environmental NGO, The Black Fish, puts it: "We have all the laws we need. What we need to do is ensure that they are respected."2 Paul Watson, founder of the Sea Shepherds' Conservation Society puts it more

\footnotetext{
${ }^{2}$ Interview with Author 2016
} 
bluntly. "States are not enforcing the law, so we have to". 3

The area of human rights provides something of a bridge between an understanding of NGOs as advocates, and NGOs in an enforcement role. Human rights NGOs are the prototypical advocates (Keck and Sikkink 1998; Sikkink 2011). Yet rather than just campaigning for governments to adhere to international human rights laws, human rights NGOs also collect evidence and carry out investigations, often liaising closely with the police and judiciary (Gonzalez-Ocantos 2014; Gallagher 2016). More than this, scholars have shown how, since the 1970s, especially in a Latin American context, NGOs have undertaken private criminal prosecutions, working either directly or through victim's families (Moyn 2010, Sikkink 2011, Michel and Sikkink 2013; Dancy and Michel 2016; Michel 2018).

As we show in the following sections, similar enforcement tactics have spread to the environmental and anti-corruption spheres, but also taken on a more transnational cast. Whereas, for example, an Argentine NGO may investigate and prosecute domestic human rights abuses in a national court, the enforcement actions discussed in the case studies to follow are much more likely to be in response to cross-border crimes. This is because either the enforcers are international NGOs, or because jurisdiction is unclear (as on the high seas), or because the crime itself crosses borders (e.g., money corruptly taken from country A is laundered in country B). Thus although NGOs enforcing domestic human rights are bolstering international law, sometimes acting through international courts, environmental and anticorruption NGO enforcers more clearly epitomize the transnational, global governance aspect of this role.

\footnotetext{
${ }^{3}$ Quoted in Hoek 2010, 177.
} 
The categories of transnational activism identified here — advocacy and enforcement—are not mutually exclusive. Many NGOs that undertake transnational enforcement also engage in advocacy, provide technical assistance to states, etc. Nevertheless, there is an important analytical distinction between these roles.

\section{Conceptualizing Transnational Enforcement}

In this section, we distinguish different NGO enforcement strategies. Some of these strategies are new, others are relatively routine. Our argument is that these old and new practices should be understood as jointly constituting a new and discrete concept of NGO enforcement.

Law enforcement can be defined as action(s) aimed at compelling (rather than encouraging or facilitating) compliance with the law. Among lawyers and policing experts, it is generally understood to involve detection, investigation, arrest, indictment, prosecution, conviction and punishment of persons that violate the law (Akella and Canon 2004, 4-5; Yang 2006, 1134-5; Interpol 2019). These activities are traditionally carried out by police, public prosecutors, and other state-mandated law enforcement authorities (Michel 2018; Edmonds and Jugnarian 2016). As we shall see, however, NGOs increasingly contribute to all elements of this enforcement chain - internationally and domestically-with or without direct consent of states. $^{4}$

As the above definition indicates, there are different elements of enforcement, including detection, investigation, arrest, prosecution, and conviction. It is rare for one type of enforcer

\footnotetext{
${ }^{4}$ Insofar as litigation, prosecution and conviction relies on courts, NGO enforcement depends on the state's legal apparatus as we discuss further later. Yet, insofar as courts are generally independent of governments, NGO enforcement does not depend on direct state involvement or consent.
} 
to perform them all. As exemplary enforcers, police do detective and investigative work and make arrests, but generally do not prosecute, and cannot convict. Prosecutors prosecute, and may investigate, but do not arrest or convict. Different NGO enforcers perform different elements of enforcement, but as with police, prosecutors, and judges, no NGO does them all.

Enforcement includes both criminal and civil law actions. The idea that civil litigation by private parties constitutes law enforcement is routine and explicit in domestic legislation, and in some international treaties. Examples include Titles III of the Americans with Disabilities Act, Title III of the Helms-Burton Act (Cuban sanctions), and articles 101 and 102 the Treaty on the Functioning of the European Union on anti-trust law (Hampton 2005; Clagett 1996; Wils 2017). This fact is a commonplace for regulatory and legal scholars (Ayres and Braithwaite 1991; Burbank et al. 2013; Fine 2017; Buxbaum 2019). Historically, law enforcement by private parties has been the rule rather than the exception (Doak 2008; Michel 2018). Recently, scholars have documented a sharp increase in climate litigation cases brought by NGOs against governments and corporations on the basis of both public, civil and international law (Harrison 2014; Edmonds and Jugnarian 2016; Ryngaert 2016; Gwynn 2019)..$^{5}$

Though we are primarily interested in NGOs enforcing international law, particular opportunities to do so often arise in national courts. Many scholars have noted a growing tendency of international law to be enforced in domestic courts, especially in the area of human rights (Michel and Sikkink 2013, 876; Dancy and Michel 2016, 173; Gallagher 2017, 1667; Gonzalez-Ocantos 2014,481; Michel 2018, 9), but also in other areas (Efrat and Newman 2019;

\footnotetext{
${ }^{5}$ In some jurisdictions, like the US, there is a sharp separation between civil (tort) law and criminal law. A tort is a civil wrong, where the individual damages or losses suffered due to a crime are separated from the harm caused to society in general (Dyson, 2014), but many other domestic and international jurisdictions allow legal action brought in defence of a collective or 'general interest' (actio popularis).
} 
Quintanilla and Whytock 2012). We refer to such instances as transnational litigation- that is, a legal process before a domestic court involving a foreign element and brought by a nongovernmental actor (as opposed to a statutory prosecuting authority). The legal process may be civil or criminal, and the foreign element may involve the litigant or defender being foreign, or the application of international law in a domestic setting (Quintanilla and Whytock 2012).

Rather than discussing the enforcement of norms, informal rules, or soft law-areas where the absence of legal obligation implies that enforcement also tends to be based on "soft" means such as persuasion or shaming — we concentrate on hard law. This provides the clearest test of our argument that NGOs have taken on more active enforcement duties, even in the domain where states' monopoly on enforcement has been presumed to be most robust. Some of the NGO enforcement activities we discuss may themselves be of uncertain legality, perhaps tipping over into vigilantism, a point we return to in the conclusion. Finally, enforcement is a means to the end of compliance, not an equivalent concept. Not all measures that boost compliance comprise enforcement (on compliance, see Raustiala and Slaughter 2002; Hillebrecht 2009; Simmons 2010; von Stein 2010; Martin 2012).

The Enforcement Spectrum: Indirect and Direct Action

NGO enforcement activities fall on a spectrum from indirect action, focused on monitoring, surveillance and investigation, to direct action, including civil litigation, criminal prosecution, and interdiction.

NGOs whose work falls in the first category often take the initiative in gathering evidence, investigating crimes, and acting as expert witnesses at court (Nurse 2013). Two aspects 
distinguish the surveillance and investigation carried out by these groups from the standard (delegated) monitoring services which have been the focus of much extant scholarship (e.g., Raustiala 1997; Gemmil and Bamidele-Izu 2002; Tallberg et al. 2014; Tallberg 2015). First, it is carried out autonomously of particular governments, even if it ultimately relies on statecreated law and courts. Even where NGO enforcement activities may align with state preferences, the latter do not cause or explain the former. Equally, it is important not to equate the state as an institutional ensemble including the whole judicial apparatus with particular governments (Gonzalez-Ocantos 2014, 480; Dancy and Michel 2016, 175). An independent court system exists in many countries precisely to hold governments to account for their compliance with and adequate enforcement of national and international law.

Second, rather than monitoring overall compliance, this form of autonomous surveillance and investigation is directly aimed at specific violators, designed to ensure they are subject to formal legal penalties. This is a crucial distinction. Investigation conducted with the aim of gathering evidence that can lead to trial and form the basis of legal judgement constitutes a crucial dimension of the judicial process (Gallagher 2017). Contrary to the spontaneous or delegated monitoring carried out by many advocacy NGOs, the activities of enforcement NGOs thus comprise independent and unsolicited efforts to expose and penalize international crime (Brenner 2007, 59-60) - a fact the International Relations scholarship has not yet properly appreciated.

Direct enforcement entails NGOs taking direct preventive or punitive actions against lawbreakers. Groups such as The Sea Shepherds Conservation Society and The Black Fish have confiscated or sabotaged equipment used for illegal fishing, and instituted maritime blockades 
against vessels engaged in illegal fishing, while Greenpeace infamously boarded the cargo ship APL Jade, suspected of hauling contraband mahogany from Brazil. ${ }^{6}$

Direct enforcement by NGOs may also include civil or criminal litigation. As discussed, international NGOs often initiate legal proceedings where statutory agencies fail to prosecute crimes (Aggraval 2008, 933; Rothwell 2013). In France, anti-corruption NGOs have taken advantage of legislation prompted by the UN Convention Against Corruption giving them legal standing to initiate criminal corruption prosecutions. ${ }^{7}$ Based on international law against corruption and money laundering, other groups like Asociación Pro Derechos Humanos de Espana in Spain, TRIAL in Switzerland, and Corner House in Britain have done the same (Moerloose 2016). Environmental NGOs have sued companies and governments before domestic courts for offences derived from international law, such as illegal whaling (Humane Society International $v$ Kyodo, Australia 2008) and contributions to global warming (Greenpeace and Nature and Youth v. Norway 2017, and Urgenda v. Kingdom of the Netherlands 2015) (Rothwell 2013; Ryngaert, 2013; Edmonds and Jungnarian 2016). Again, such direct and autonomous enforcement stands in contrast to NGOs as delegated monitors, or as advocates that seek to lobby or shame government into exercising state investigative and coercive powers.

One might object that our distinction between indirect and direct enforcement is insufficiently sharp to serve as a useful taxonomy. Many direct enforcement actions have indirect effects in the form of "demonstration effects" or, as we show in the cases, by provoking government action. Yet the distinguishing feature of a direct enforcement action as we conceive it is that-

\footnotetext{
${ }^{6}$ www.nytimes.com/2003/10/11/us/typical-greenpeace-protest-leads-to-an-unusual-prosecution.html

${ }^{7}$ Law of December 6, 2013; Perdriel-Vaissiere 2017, 10.
} 
even if states choose not react at all-it still has an effect (in halting or interrupting a specific crime, or triggering judicial review). Indirect actions by contrast depend on further government action to have any effect at all (Eilstrup-Sangiovanni and Bondaroff 2014).

\section{Explaining the Rise of NGO Enforcement}

While they are not always new, transnational law enforcement practices are spreading. Before the 1970s in the environmental sphere (Eilstrup-Sangiovanni 2019), and before the 1990s when it comes to anti-corruption, there was little enforcement of international law, because there were few if any international laws governing these areas. As such, transnational enforcement in both policy domains is by definition relatively recent. Even in the human rights scholarship referenced earlier, private prosecutions mainly date from the 1980s onward.

The expansion in transnational law enforcement activity is explained by changes in both demand and supply factors. On the demand side, a rapid proliferation of international laws without a corresponding increase in state enforcement capacities has produced a growing “enforcement gap" to be filled by NGOs (Nurse 2013). On the supply side, technological and legal advances have reduced costs to NGOs of supplying transnational enforcement. As Büthe has pointed out $(2012,38)$, and as our case studies demonstrate, the changes effected by these demand- and supply-side factors reflect inherently political strategies and choices by NGOs that seek to take advance of new legal and technological opportunity structures to advance their aims, rather than impersonal market forces. Nor do we hold any presumption of equilibrium as the natural outcome; even with increasing enforcement efforts by NGOs, the enforcement gap looks unlikely to be eliminated any time soon. 


\section{The Demand Side: Expansion of International Law}

The past few decades have witnessed a rapid proliferation of international laws criminalizing certain transnational activities, from money laundering, corruption, and insider trading to trafficking in weapons, drugs and endangered wildlife (Abbott and Snidal 2009; Betts 2013, 69; Simmons et al. 2018, 249; Alter and Raustiala 2018). However, enforcement remains limited (Interpol 2019). Implementation of international laws is often entrusted to IGOs that lack jurisdiction to enforce treaties without assistance from party states (Ardia 1998, 511). On the other hand, national enforcement agencies are generally confined to operating within a particular jurisdiction and may lack financial and technical capacity (or inclination) to enforce laws outside national borders. The gap between formal commitments (and public expectations) of a law-based global system and state enforcement capacities is thus widening.

\section{The Supply Side: Technological and Legal Advances}

Organizational innovation is often fueled by advances in technology. In recent decades, the growing sophistication and declining costs of remote-sensing technologies such as Global Positioning Systems (GPS) and Geographic Information Systems (GIS), and new aerial surveillance tools such as drones, have enabled NGOs to contribute more directly to law enforcement. For example, low-cost unattended ground sensor systems and drones have permitted small and resource poor NGOs to reveal illegal poaching activities on land and at sea. Similarly, anti-corruption activists in Russia have used drones to investigate and film mansions and estates owned by politicians accused of corruption. ${ }^{8}$ As we show in the case studies, some NGOs like ShadowView and Skytruth now focus exclusively on making hightech remote sensing technologies and satellite and aerial imagines available to other NGOs for

\footnotetext{
${ }^{8}$ For the results, see https://www.youtube.com/watch?v=3eO8ZHfV4fk.
} 
surveillance purposes. $^{9}$

Anti-corruption investigations have also been greatly assisted by a range of online tools, starting with simple Google searches on individuals and companies. Screen-scraping software can harvest vast amounts of financial data from the web for sifting and analysis. The NGO Open Corporates has scraped, organized, and made public data on over 100 million companies drawn from dozens of corporate registries around the world. ${ }^{10}$ In analyzing this material to mount investigations, NGOs routinely use the same sort of case organization, network analysis, and forensic accounting software used by law enforcement agencies, which can be bought off the shelf, often quite cheaply. ${ }^{11}$

A second development facilitating NGO enforcement are legal advances expanding the rights and opportunities for NGOs to engage in private prosecution, or more generally as formal participants in civil court actions. International treaties such as the Aarhus and Alpine Conventions widen the scope for NGO participation in legal proceedings regarding environmental harms. While some countries have granted private prosecution rights for centuries (see Dancy and Michel 2016), changes to procedural laws in many countries have widened such rights by extending locus standi to NGOs to sue behalf of underrepresented thirdparties, or on basis "public interests" (actio popularis) (Rebasti and Vierucchi 2002; Edmonds and Jugnarian 2016; Stephenson 2016). ${ }^{12}$ For example, recent case law has confirmed private prosecution rights for European NGOs in environmental matters (e.g., Trianel (C-115/09, European Court Reports 2011 I-03673). Scholars also note a growing trend towards

\footnotetext{
${ }^{9}$ http://skytruth.org/issues/oceans/\#sthash.Kxq08LDO.dpuf; http://soarocean.org/project-details.

${ }^{10} \mathrm{https}: / /$ old.datahub.io/dataset/opencorporates

${ }^{11}$ Author interview, The Sentry, Brisbane Australia, 27 October 2016; Global Witness, Exeter, UK, 18 September 2015.

${ }_{12}$ An example of accommodating legislation is the Polish Environmental Protection Act, according to which NGOs may file an action in cases of threat to or damage to the environment as the "common good". Ibid.
} 
international tribunals addressing questions of a collective or public nature, including infringement of environmental laws. Alter has noted the creation of almost 20 new international courts from the end of the Cold War, distinguished by the opportunities they provide for nonstate actors to initiate enforcement actions (Alter 2011: 389, 392; Alter 2014: 66; also Rebasti and Vierucchi 2002; Harrison 2014). Tallberg et al. (2014) argue for a similar expansion in the political opportunity structure, as IGOs have become more willing to open up to and make common cause with NGOs (see also Green 2010; Johnson 2016). Scholars thereby single out enforcement as an area of growing opportunities for non-state actors, though their understanding of enforcement is mainly associated with delegated or orchestrated monitoring (Tallberg et al. 2014, 19 and 32; Tallberg 2015, 171).

\section{Cases and Expectations}

This section illustrates our argument with evidence from the environmental protection and anticorruption sectors. We focus on these sectors for two reasons. First, unlike human rights where international legal frameworks have a longer pedigree, both areas have seen a recent expansion of international laws and governance procedures, which combined with limited state enforcement, has produced an enforcement gap. Both areas are also characterized by the recent introduction of specific legal and technological tools which facilitate independent NGO enforcement. This allows us to carefully observe the relationship between changing demand and supply factors and growing transnational enforcement. Second, a focus on transnational anti-corruption and environmental enforcement allows us to expand on earlier coverage of enforcement actions by human rights groups in showcasing the full range of NGO enforcement activities - from indirect to direct enforcement, from monitoring and surveillance to interdiction and litigation - in new policy domains and on a wider transnational basis. 
We first establish the changing contextual factors giving rise to increasing NGO enforcement in each area, before illustrating and substantiating the range of NGO enforcement measures in line with our descriptive and conceptual aims. The cases thus both serve as a plausibility probe of our causal argument regarding changing demand and supply factors, while also demonstrating the merit of the concept of transnational enforcement as a new phenomenon worthy of study (Gerring 2017, 20; Mahoney 2015, 201). Both cases show clear variation across time, reflecting the relationship between a proliferation of international laws, increased opportunities for enforcement beyond the state, and the associated rise of NGO enforcement.

\section{Environmental Enforcement}

\section{Growing Legalization}

Environmental law is among the fastest growing areas of international law. ${ }^{13}$ Since the 1972 Stockholm Conference on the Environment, world leaders have signed more than 1,300 international agreements governing areas such as biodiversity, atmospheric pollutants, chemicals, illegal fishing, desertification, destruction of tropical forests, marine plastics pollution, endangered species, hazardous substances and waste, toxic dumping, and many more (Tseming and Persival 2009, Mitchell 2017). Yet despite the proliferation of environmental laws, detection and punishment of environmental crimes remain low, as states often lack capacity and will to enforce laws against crimes crossing national jurisdictions (Akella and Allan 2012, 6-7; Interpol 2019). Thus, global environmental governance has become simultaneously highly legalized and poorly enforced.

\footnotetext{
${ }^{13} \mathrm{http}: / /$ guides.11.georgetown.edu/InternationalEnvironmentalLaw
} 


\section{Technological and Legal Advances}

As demand for environmental law enforcement has increased, technological advances have reduced the cost to NGOs of monitoring, investigating, and disrupting environmental crimes. Commercially available drones, GPS and other remote sensing technologies enable environmental NGOs to extend monitoring and surveillance across vast areas. Cheap cell phone-enabled camera traps and unattended ground sensor systems allow rangers to collect reliable evidence of wildlife poaching, illegal logging, and other criminal activities (see Eilstrup-Sangiovanni 2019). While advanced monitoring technologies like satellite, radar and surveillance aircraft have traditionally been the preserve of militaries and governments, declining costs means these technologies are now widely available to NGOs. ${ }^{14}$

Technological innovation has been accompanied by legal changes allowing environmental NGOs to gain the status of injured parties before international and national courts. In a European context, the UNECE Convention on Access to Information, Public Participation in Decision-making and Access to Justice in Environmental Matters (Aarhus Convention), which came into force in 2001, obliges national courts to grant legal standing to NGOs to challenge new legislation or projects likely to harm the environment. The legal standing of NGOs was confirmed in a landmark ruling in May 2011 by the European Court of Justice (Trianel C115/09). Many European states (e.g., France, Portugal, Italy, and the UK) grant environmental NGOs direct access to civil courts, along with the right to intervene in national criminal proceedings, and to claim compensation for environmental damage on behalf of affected citizens or the general public (de Sadeleer et al., 2002). Such legislative changes-combined with an increase in environmental courts and tribunals worldwide (Preston 2016) - have expanded opportunities for NGOs to prosecute environmental crimes (Harrison 2014; also

\footnotetext{
14 http://soarocean.org/why-drones/
} 
Eilstrup-Sangiovanni 2019).

\section{Indirect and Direct Enforcement}

Beyond substantiating our key expectation that changing demand and supply factors lead to growing NGO enforcement, the examples of transnational environmental enforcement presented below cover a wide spectrum-from surveillance and investigation through to litigation and direct interventions against environmental crime.

There is abundant evidence that environmental NGOs increasingly tap new information and communication technologies to expand independent monitoring. For example, drones have been widely used by NGOs such as SeaScope, SoarOcean, International Wildlife CrimeStoppers, and Blue Seals to reveal poaching activities on land and at sea. The "Flying for Wildlife Trust" carries out aerial monitoring of elephants in Zimbabwe to expose poaching, while the tiny NGO SkyTruth has used satellite imagery to document oil-spills in place like East Timor (2009) and Kuwait (2017) and bilge dumping off the cost of Fujairah in the United Arab Emirates (2017). In 2014 SoarOcean launched Global Fishing Watch, a sophisticated monitoring network which uses satellite tracking to detect when and where commercial fishing is happening in every ocean around the world in real time with the goal of facilitating more effective intervention against illegal fisheries (see Eilstrup-Sangiovanni 2019). While these groups all supply evidence to government authorities to facilitate arrests and prosecution, their monitoring activities are self-directed and autonomous, funded by charitable donations rather than by governments or IGOs, and explicitly designed to gather evidence of criminal conduct which can be used to build case files. 
An example of a group specializing in indirect enforcement through independent investigation is the Environmental Justice Foundation, a UK-based NGO founded in 2001 that works internationally to expose illegal fishing and human rights abuses. Among recent projects, the group has investigated exploitation of workers in the cotton industry in Uzbekistan, and illegal exploitation of mangrove forests in Brazil. In 2012, the EJF launched the Fisheries Information Network (FIN) across West Africa. Using remote sensing technologies, FIN collects data and evidence on suspected illegal fishing and issues alerts to coastal, flag and port states. According to EJF's website, ${ }^{15}$ evidence gathered through FIN has prompted arrests and millions of dollars of fines levied against pirate fishing vessels by the governments of Korea and Sierra Leone, and by EU authorities. Another group with a similar profile is Eco-Activists for Governance and Law Enforcement (EAGLE) which carries out investigations and assists governments with arrest operations and litigation in order to "generate a strong deterrent against the illegal trade in wildlife, timber and related criminal activities."16

Further examples of NGOs whose work falls at the indirect end of the enforcement spectrum include the Environmental Investigation Agency (EIA), which specializes in undercover investigations of environmental crime, ${ }^{17}$ and the Wildlife Justice Commission (WJC) whose mission is "to disrupt transnational organized wildlife crime by exposing criminal networks... and by empowering-or, if need be, pressuring-governments to enforce their laws." ${ }^{18}$ Similar to TRAFFIC, ${ }^{19}$ the WJC and EIA both supply data and evidence to wildlife and customs enforcement agencies, including Interpol and the World Customs Organization.

\footnotetext{
15 https://ejfoundation.org (Assessed December 2018)

$16 \mathrm{http}$ ://www.eagleenforcement.org/crisis (Assessed 20-05-2919)

17 https://eia-international.org/about-eia/ (Assessed 20-05-2919)

18 https://wildlifejustice.org/about-us/ (Assessed December 2018)

${ }^{19}$ A decision by the Parties to the Convention on Biological Diversity and CITES has entrusted TRAFFIC (an initiative governed by The WWF and the International Union for Conservation of Nature) to undertake certain inspections within the territory of Treaty Parties in cooperation with the Secretariat of CITES.
} 
Unlike TRAFFIC, however, neither NGO has been delegated specific monitoring responsibilities by IGOs or governments. Furthermore, both groups pursue an explicit strategy of pressuring reluctant governments to enforce the law. In July 2016 after Vietnamese authorities failed to act on a 5,500 pages Case File submitted by WJC containing evidence regarding Chinese and Malay wildlife traffickers operating in Vietnam, the WJC convened a public hearing in The Hague. Over the course of two days, WJC presented evidence to a Designated Independent Review Panel composed of international law experts, which issued a set of recommendations to Vietnamese authorities. ${ }^{20}$ By forcing the issue onto the global stage, the WJC compelled the Vietnamese government to take action, leading to a string of arrests and prosecutions, which upended nine major trafficking networks involved in the supply of ivory, rhino horn, and tigers. ${ }^{21}$

Like NGOs fighting corruption, environmental NGOs increasingly use litigation as an enforcement tool. In 1991 Greenpeace activists blocked the outflow pipe of the Albright \& Wilson plant in Cumbria, England, following months of research which established that the outflow from the pipe was in violation of the 1989 Water Act. ${ }^{22}$ Based on evidence gathered, Greenpeace launched a successful private prosecution against Albright \&Wilson under the Water Act 1989 for discharging excessive amounts of heavy metal into the Irish Sea (Edmonds and Jungnarian 2016). In 2008, Humane Society International brought a lawsuit against a Japanese whaling company before an Australian court for killing whales within Australia's Antarctic whale sanctuary in contempt of a 2008 injunction. ${ }^{23}$ In 2017 the NGO Oil Spills

\footnotetext{
${ }^{20}$ https://wildlifejustice.org/about-us/

${ }_{21}$ Opcit., and National Geographic: https://www.nationalgeographic.com/animals/2018/07/wildlife-watch-newscaptive-tiger-farms-trafficking-investigation-vietnam-laos/

22 Business Library. “Greenpeace Wins Pollution Case.” September 16, 1991. http://findarticles.com/p/articles/mi_hb5255/is_n18/ai_n28606353/ (Accessed April 11, 2012).

${ }^{23} \mathrm{https}: / /$ www.theguardian.com/environment/2015/nov/18/australian-court-fines-japanese-whaling-company$1 \mathrm{~m}$-for-intentional-breaches
} 
Victims Vanguard filed a civil suit in the High Court in London against Shell Nigeria Exploration and Production Company on behalf of the victims of a 2011 oil spill in Nigeria's Niger Delta region.

Civil litigation is not merely directed against corporations. In 2016, Greenpeace and the NGO Nature and Youth sued the Norwegian government for contributions to climate-change. The lawsuit was facilitated by a recent change in the Norwegian Constitution, which makes preserving a healthy and diverse environment a legal obligation for the government. ${ }^{24}$ However, the case rested not on local harms...but on the contribution any oil extracted will make to global warming which the Paris accord of 2015 obliges governments to reduce (Ryngaert 2013). In 2015, Stichting Urgenda v The State of the Netherlands, an injunctive relief was sought obliging the Dutch state to reduce its per capita greenhouse gas emissions, which the plaintiff argued was among the highest in the world. The Hague District Court accepted jurisdiction and gave standing to the Urgenda Foundation on grounds that its by-laws stated it represented global interests (Gwynn 2018:17). Though the case turned on whether the state had breached its duty of care under the Dutch civil code, the court invoked international instruments, ruling that the 1992 UNFCCC, EU legislation and the ECHR had a "reflex effect" upon the duty of care of the Dutch civil code (ibid.). On this basis the Court ordered the Dutch state to institute more aggressive limits on the volume of greenhouse gas emissions by 2020 (Gwynn 2018:17).

These are just a handful among hundreds of examples of how environmental NGOs are increasingly taking to the courts-using domestic courts to enforce compliance with

\footnotetext{
${ }^{24}$ The Oslo District Court ruled in favor of the Norwegian Government on January 4, 2018. Greenpeace has appealed the decision.
} 
international laws, and strategically selecting jurisdictions in order to exploit differences in national courts' openness to private litigation (Ryngaert 2016, Harrison 2014).

Further along the enforcement spectrum, the Sea Shepherds Conservation Society (SSCS) provides a leading example of an NGO favoring a direct enforcement approach. Headquartered in Amsterdam, the SSCS operates a fleet of ten ships that navigate the world's oceans to combat illegal fishing. ${ }^{25}$ Unlike many NGOs, the SSCS defines its mission exclusively as international law enforcement. "We're not a protest organization, we're a policing organization," says SSCS founder, Paul Watson. ${ }^{26}$ The group is notorious for its confrontational actions which have included ramming and scuttling whaling ships, physically intervening in seal hunting, and seizing and destroying illegal drift-nets at sea (Eilstrup-Sangiovanni and Phelps-Bondaroff 2014).

Despite its extreme tactics the SSCS takes care in navigating the uncertain line between vigilantism and law enforcement, carefully selecting targets where legally binding conservation measures are in place which states are unable or unwilling to enforce (EilstrupSangiovanni and Phelps-Bondaroff 2014). In 2011, during NATO's bombing campaign in Libya, the EU ruled none of its members could fish in Libyan waters as there was no way to check licenses and enforce quotas in a war zone. In June 2011, the SSCS dispatched two ships to patrol the coastal waters of Libya, their crew fitted with bullet-proof vests, in order to prevent unregistered tuna-fishing boats from taking advantage of the absence of official inspections. ${ }^{27}$ "We will be armed with the regulations and in touch with NATO and the EU Commission if we encounter any suspicious activity," said SSCS President, Paul Watson (Neville 2011). In a

\footnotetext{
${ }^{25}$ http://www.smh.com.au/national/how-sea-shepherd-stays-afloat-20120110-1ptu6.html

26 http://www.seashepherd.org/who-we-are/mandate.html

$27 \mathrm{http}: / /$ news.discovery.com/earth/protecting-tuna-from-libya-war-110519.htm
} 
similar operation in 2010, the group deployed five divers to cut the nets towed by the Cesare Rustico - an Italian vessel hauling two cages of Bluefin tuna caught in Libyan waters - thereby releasing 800 tons of illegally fished tuna back into the Mediterranean Sea. Despite not being officially sanctioned to carry out inspections, the SSCS vehemently deny charges of vigilantism. "We do have authority", insists SSCS Captain Hammarsted. "We have the right to intervene in accordance with the UN's World Charter for Nature that allows for NGOs to intervene to uphold international conservation law and specifically in areas beyond national jurisdiction" (quoted in Neville 2011).

Another striking example of direct enforcement is the SSCS's interception of the Nigerianflagged ship, Thunder, in 2015. The Thunder, a Norwegian-built trawler owed by Panamanian shell company, had been wanted by Interpol since 2013 for illegal toothfish fishing, yet no government had taken steps to apprehend it. SSCS spent more than $\$ 1.5$ millions over three months in chasing the fugitive vessel, before finally prompting the captain to scuttle the ship at sea to conceal its crimes (Milman 2015). As the ship sank, SSCS crew boarded it and seized evidence of its unlawful activities (including the captain's logbook, cell-phones and computers, and a 200-pound toothfish). Next, they escorted the captain and crew to shore where they were detained until placed under arrest by Interpol. This evidence submitted by SSCS to Interpol led to conviction of the captain and two senior crew members on charges of illegal fishing. ${ }^{28}$

The SSCS is not alone in taking a direct approach to environmental law enforcement. The Black Fish, founded in 2010, has used drones to pinpoint the location of illegal drift-nets which

\footnotetext{
${ }^{28}$ https://www.interpol.int/News-and-media/News/2015/N2015-160; and http://www.scoop.co.nz/stories/HL1503/S00046/interpol-takes-custody-of-evidence-from-sea-shepherd.htm. Interpol declined to publicly acknowledge assistance or receipt of evidence from SSCS. However, Interpol representatives unofficially applauded the operation. "They're getting results" an Interpol official (speaking anonymously) said (Urbina 2015; Interview with author Oxford Jan 2016).
} 
the group has subsequently confiscated and destroyed. Similar to SSCC, the group has also used divers to release illegally caught bluefin tuna from cages at a fish farm in Croatia. "We don't see ourselves as witnesses, more as enforcers of law. We want evidence of illegality and we are prepared to take direct action," says founder of The Black Fish, Wietse van de Werf. ${ }^{29}$

Like the SSCS, The Black Fish systematically targets problems defined by an enforcement gap. Thus in recent years the group has focused on confiscating driftnets and illegal Fish Aggregation Devices off the Coast of Sicily, where they say enforcement has been particularly low due to the Italian Italian coastguard "being stretched with the migrant issue" (Interview, 2016).

Direct enforcement is carried out autonomously of states, but it often has states at a main target audience. Along with many other groups engaged in direct enforcement, The Black Fish articulates a clear strategy of seeking to pressure states to improve law enforcement by challenging their enforcement authority monopoly. As van de Werf, explains:

We feel...the moment we have a vessel out there collecting driftnets from the ocean, as soon as we get into any confrontation with illegal driftnets vessels, the coast guard or the Navy will come out and then it's going to be interesting because they are actually supposed to do the work we're doing there. So, I think what we're trying to do is to really provoke a reaction from the authorities by starting the work for them. ${ }^{30}$

29 Author Interview, London, June 2016; Vidal 2012.

${ }^{30} \mathrm{http}: / /$ www.monbiot.com 
Thus it is crucial to appreciate that rather than just being some abstract, analytical classification, these NGOs understand themselves as enforcers, and explicitly claim this mantle.

\section{Anti-Corruption Enforcement}

\section{Growing Legalization and the Enforcement Gap}

International anti-corruption treaties and conventions have proliferated since the mid-1990s, including the Inter-American Convention against Corruption (1996), the OECD Anti-Bribery Convention (1997), the Council of Europe Convention on Corruption (1999), and high-profile anti-corruption commitments from many other inter-governmental organizations (McCoy and Heckel 2001; Abbott and Snidal 2002; Fisman and Golden 2017). Increasing international legalization was capped by the 2005 United Nations Convention Against Corruption. This trend entailed a corresponding increase in domestic anti-corruption legislation, as international commitments were written into national law. Corruption, particularly as committed by senior state officials, is now seen as an inherently transnational problem, in that bribes and stolen money tend to cross borders, rather than being simply an internal law enforcement problem (StAR 2010; StAR 2014).

Despite the proliferation of anti-corruption law, effectiveness is widely regarded as very low, even among law enforcement agencies and anti-corruption NGOs (Sharman 2017). Transparency International-UK has endorsed earlier UN findings that only around one percent of illicit funds are detected, and an even smaller proportion actually confiscated (Transparency International-UK 2015, 6). This effectiveness gap reflects enduring challenges: international corruption cases are slow and legally complex, given the need to reconcile different jurisdictions' legal traditions and procedures in international cases, and often involve delicate 
diplomatic questions (StAR 2010, 2014). Hence the global governance of corruption has become simultaneously highly legalized and poorly enforced.

\section{Technological and Legal Advances}

As increased legalization and conspicuous shortcomings in states' anti-corruption efforts have accentuated the demand for enforcement, technological and legal advances have reduced the cost of supply for non-state actors. The 1990s saw the privatization of financial surveillance, as banks were made responsible for anti-money laundering monitoring, and later for countering the financing of terrorism and enforcing targeted financial sanctions (Zarate 2013). This stimulated the development of a financial compliance industry, and accompanying software (Tsingou 2019). The steadily falling price of computing power and the proliferation of free or cheap analytical software means that even small NGOs can utilize this technology to access vast amounts of newly available information. This includes information from corporate and property registries made freely available online by governments in searchable format, together with vast leaks of hitherto secret financial data in the Panama and Paradise papers (Obermayer and Obermaier 2016). In combination, these developments mean that a single individual now probably has more financial investigative capacity than the best resourced law enforcement agency in the mid-1990s, when international laws against corruption were first passed.

Innovations in civil and criminal law have complimented these technological advances in favoring non-state enforcement at the international and domestic level. Private parties can increasingly use civil law remedies to forcibly obtain evidence, freeze funds, and confiscate assets, including those in foreign jurisdictions (Thelesklaf and Pereira 2011). For example, new “Anton Piller" court orders authorize plaintiffs to search defendants' residences and places of business unannounced for evidence (commonly financial records), with refusal treated as 
contempt of court. Similarly, "Mareva" injunctions allow plaintiffs, and even those who are not party to the original case, to freeze defendants' bank accounts and other assets pending resolution of the case, sometimes with world-wide effect (Daniel and Maton 2008; Oliver 2011). In the United States the Racketeering Influenced and Corrupt Organizations (RICO) law passed in 1970 to fight the mafia is now overwhelmingly used by private parties, including NGOs, to restrain and seize the assets of other private parties using either criminal or civil law remedies. ${ }^{31}$ As discussed below, recent legislative changes, often stimulated by new international law like the UN Conventions against Transnational Organized Crime (2003) and Corruption (2005), also give or expand the right of non-state actors to bring private criminal prosecutions, including for corruption-related offences (Messick 2016; Edmonds and Jugnarian 2016; Stephenson 2016). The actions of states and IGOs have created political opportunities and spaces for NGO action, but the NGO actions themselves are autonomous, rather than being directed, contracted or orchestrated by particular governments.

\section{Indirect and Direct Enforcement}

Having established the presence of the demand and supply conditions associated with growing transnational enforcement of international anti-corruption laws, it now remains to evidence the results by surveying the range of autonomous NGO enforcement. This extends from monitoring and investigation, through to civil litigation and criminal prosecution.

Global Witness has been perhaps the most successful investigative group. It has specialized in corruption in the resource extraction sector, where it has used a combination of open source material, illegal leaks, undercover investigative work, and sting operations to build highly

31 “Taking the Gangster Rap" Economist, August 6, 2015 
detailed accounts of individual corruption offences. For example, a 2009 report accused leaders from Equatorial Guinea, Congo, Gabon, Liberia, Angola, and Turkmenistan of specific corruption offences. It also named banks including Citibank, Deutsche, Barclays, and HSBC as laundering the proceeds. The report even published individual bank account details, the credit card statements of the son of the Congolese president, and a copy of the Barclays Bank check used by Obiang of Equatorial Guinea to buy one of his many Ferraris (Global Witness 2009, 44). Global Witness has since published the results of much other detective work. ${ }^{32}$ Though Global Witness has accepted funds from various state development agencies, its investigations are conducted independently of governments and law enforcement agencies; its findings are usually highly critical of state authorities for the inadequate enforcement of their international anti-corruption and anti-money laundering commitments.

The Sentry, founded and in part funded by George Clooney, specializes in the link between corruption and war crimes in East Africa. It describes its mission as "creating a significant financial cost to... kleptocrats through network sanctions, anti-money laundering measures, prosecutions, and other tools." ${ }^{33}$ A 2016 project on corruption among the leaders of South Sudan saw investigative teams dispatched to Australia, Egypt, Ethiopia, Kenya, South Sudan, and Uganda to interview witnesses. The resulting report accused specific individuals of major corruption offences, and traced the contracts, bank transfers, and property records to follow the money trail, with many of the key primary documents reproduced in the report (Sentry 2016). Once again, rather than being contracted, enlisted, or somehow orchestrated by a state or intergovernmental organization, this investigation took place in an environment of official indifference or hostility. The Sentry's UK office is led by the former head of the British

\footnotetext{
${ }^{32}$ https://www.globalwitness.org/en-gb/

${ }^{33}$ https://thesentry.org/about/.
} 
National Crime Agency's Overseas Corruption Unit, indicating the level of investigative expertise even small NGOs can secure.

While Global Witness has focused mainly on investigative work, the campaign against Teodorin Obiang, Vice President and heir apparent of Equatorial Guinea showcases a broader range of NGO enforcement action, from investigation to prosecution. Obiang was convicted in French court in October 2017 of embezzlement and money laundering, while he faces another NGO-led prosecution in Spain. ${ }^{34}$ The case began in March 2007 when the Comité Catholique contra Faim et pour le Dévelopment published a report on the stolen wealth of past and current dictators stashed in the West. Working from the findings of this report and led by Sherpa (a group of lawyers working pro bono against corruption and for development), three French NGOs lodged criminal complaints against the presidents of Gabon, Congo, and Equatorial Guinea and their families for laundering the proceeds of corruption in France. Despite an initial French police investigation supporting these allegations, French prosecutors dropped the case in November 2007 (Perdriel-Vaissiere 2011, 2017).

In July 2008 Transparency International France joined Sherpa in re-filing the criminal complaint. Reflecting hostility to unauthorized enforcement, the French prosecutors fought Transparency International France and Sherpa in the courts and the press to throw out the criminal complaints, only to lose in late 2010, at which time criminal action against Obiang commenced (Perdriel-Vaissiere 2011; 2017). The French government subsequently legislated in December 2013 to allow NGOs to bring criminal corruption and money laundering charges directly to the courts, thus removing the need to re-fight this legal battle in other cases, and

\footnotetext{
${ }^{34}$ https://globalanticorruptionblog.com/2017/10/30/french-court-convicts-equatorial-guinean-vice-presidentteodorin-obiang-for-laundering-grand-corruption-proceeds/
} 
precipitating subsequent additional prosecutions by Sherpa and another new NGO, Anticor. ${ }^{35}$

Direct criminal action by anti-corruption NGOs is not limited to France. Spanish criminal law provides wide latitude for NGOs to bring criminal prosecutions. ${ }^{36}$ Asociación Pro Derechos Humanos de Espa $\square a$ (APDHE) brought money laundering cases against Obiang and several other officials in October 2008. The first arrests on this case were made in 2015. Significantly, both the French and Spanish NGOs were supported in their enforcement actions by the Open Society Foundations from New York (funded by George Soros), in part explaining how such small NGOs could undertake complex legal actions for over a decade. ${ }^{37}$

A further example of transnational enforcement working directly through the courts is the British NGO Corner House, specializing in corruption in the arms trade. Corner House challenged the decision to stop a corruption investigation against British arms company, BAE systems, in connection with a massive arms deal with Saudi Arabia. The UK Serious Fraud Office had dropped the investigation under heavy pressure from the Blair government (Gilbert and Sharman 2016). Corner House moved in court to force the government to reinstate the investigation. Memorably dismissed by one government official as a "hopeless challenge brought by a bunch of tree-hugging hippies," Corner House severely embarrassed the government by obtaining a decision in their favor (Sharman 2017, 195). Subsequently Corner House has mounted other legal challenges attempting to freeze alleged corruption proceeds in Britain. $^{38}$

\footnotetext{
${ }^{35}$ Author interview, Paris 2017.

${ }^{36}$ Sanz and Sese 2011; https://www.opensocietyfoundations.org/litigation/apdhe-v-obiang-family.

${ }^{37}$ Author interviews, OSF, New York, February 2015, April 2017; Paris, Sherpa, April 2017.

${ }^{38} \mathrm{http}: / /$ www.thecornerhouse.org.uk/sites/thecornerhouse.org.uk/files/Press\%20Release\%207\%20Nov\%202014 _1.pdf
} 


\section{Conclusions}

NGOs play a variety of different roles in global politics, increasingly including autonomous transnational law enforcement. This shift has been facilitated by recent technological developments and legal changes. In some cases, NGO enforcement activities aim at independently reinforcing state-led enforcement by providing evidence and mounting complimentary investigations. In other cases, they occur in lieu of state enforcement. Here we consider some pros and cons of NGO enforcement, and then examine the broader implications for world politics.

NGO enforcement carries a range of potential benefits. It multiplies the resources devoted to investigating and prosecuting international crime, and shifts costs from governments to the non-profit sector (see Bayley and Shearing 2001 and Ayling 2013 on benefits of private policing). Unlike official monitoring and verification systems, which have to monitor compliance with treaties universally, NGOs can focus their enforcement efforts on specific areas and countries of concern (Meier and Tenner 2001). NGOs can also bring valuable expertise and capacity to law enforcement. They are often highly motivated and knowledgeable, willing to devote time and resources to issues that state actors are unwilling or unable to pursue (Tallberg 2015, 166-67). When NGOs are independently funded they are also subject to fewer domestic political pressures than governments, and may therefore be more aggressive and consistent enforcers of international norms and standards (Ardia 1998, 560-2). Finally, from a wider societal perspective, NGO enforcement can potentially serve as a check on unresponsive states (Michel 2016). Arguably, then, NGO enforcement secures widely valued global goods that would otherwise be in short supply. 
Yet the picture is not exclusively positive. A major concern regarding "vigilante" justice is whether due process is followed to protect innocent parties from being falsely accused and punished. NGOs may be less impartial than state officials. Whereas public enforcement authorities must provide the full range of police services, NGOs are free to decide which issues to focus on and which cases to litigate, and will often make their selection strategically with a view to wider societal impact (Michel 2016), potentially leading to selective and biased enforcement practices. NGO enforcement may also raise issues of professionalism. For example, the SSCS has frequently been accused of breaching safety-at-sea regulations during its self-styled enforcement actions. ${ }^{39}$ Scholars studying policing in a domestic setting have worried that use of private policing companies may serve to weaken executive and legislative oversight of policing, thereby reducing democratic legitimacy and accountability (Bayley and Shearing 2001; Ayling 2013). A similar concern arises in regard to transnational enforcement where reliance on NGO enforcement may mean that attributing blame for enforcement shortfalls becomes harder.

Many of these concerns recall of the oft-heard criticism that NGOs are "partial, unrepresentative and unaccountable." Yet, as Price $(2003,591)$ argues, "the criticism that civil society activists are unrepresentative deflects hard questions away from the legitimacy of existing political institutions...when it is the very unresponsiveness of such institutions that creates the conditions for transnational civil society activism in the first place." In the case of transnational enforcement, the objection of lacking representativeness may be even less persuasive. Even in countries with relatively little corruption, state enforcement is often highly selective and politicized. Transnational versus state-led enforcement seems to be less a

\footnotetext{
${ }^{39}$ It is important to note that NGOs enjoy none of the immunities enjoyed by public police. Thus, Greenpeace faced criminal prosecution for boarding and boatjacking the APL-Jade, which it falsely believed carried contraband Brazilian mahogany.
} 
question of who gets to "define the public interest," than a case of NGOs defending public interests as defined by states where states and IGOs fail to do so effectively.

This defense of NGO enforcement also highlights a downside, namely that growing transnational enforcement may simply lead governments to "pass the buck" to NGOs in shirking their enforcement responsibilities (Dai 2002, 416). If so, the net effect of NGO actions to enforce international law might be zero or even negative. When asked whether he worries that by supplying enforcement where states fail their duties, NGOs effectively reduce incentives for states to enforce, van de Werf answers. "We are effectively doing their job for them. It's not ideal but the issue is urgent." 40

Some may object that the examples cited in our cases amount to little more than anecdotal evidence of a growing range and incidence of transnational enforcement. We dispute this. Though not coining these activities as enforcement, recent literature in both IR and International Law provides plenty of evidence of an increase in NGO litigation and other forms of enforcement. While clearly enabled by technological and legal changes, this increase in transnational enforcement may be partly due to an increase in the number of international NGOs. However, our argument is that autonomous NGO enforcement is not merely a quantitative change, a matter of more non-state agents contracted by state principals. Rather, NGO enforcement is qualitatively different from that practiced by for-profit corporate enforcers, or NGOs that carry out monitoring on behalf of states or IGOs. NGO enforcers interact with states neither as principals, nor as targets for advocacy, being more self-directed than these models of NGO-state interaction generally allow.

\footnotetext{
${ }^{40}$ Author interview, London, June 2016.
} 
From the perspective of International Relations scholars, the degree to which international rules can be enforced in an anarchical system is perhaps the fundamental question. So far, however, we have missed the significance of transnational enforcement, because we have lacked the right conceptualization to recognize it as such. Even in a context where the participation of NGOs in global governance is now widely accepted, a lingering state-centrism means that scholars have been slow to appreciate NGOs' role in the pluralization and decentralization of international enforcement. The contribution of our piece is thus both conceptual as well as empirical in highlighting this important but so far neglected aspect of contemporary global governance. Finally, our argument opens up new avenues for research into how legal and technological opportunity structures affect the behavior of NGOs. 


\section{Bibliography}

Abbott, Kenneth and Duncan Snidal. 2002. "Values and Interests: International Legalization in the Fight against Corruption.” Journal of Legal Studies 31(1): 141-178.

Abbott, Kenneth and Duncan Snidal. 2009. "Strengthening International Regulation Through Transnational New Governance: Overcoming the Orchestration Deficit." Vanderbilt Journal of Transnational Law 42:501-577.

Abbott, Kenneth, David Levi-Faur and Duncan Snidal. 2017. "Introducing Regulatory Intermediaries." Annals of the American Academy of Political and Social Sciences 670: 6-13.

Abrahamsen, Rita and Michael Williams. 2011. Security Beyond the State: Private Security and International Politics. Cambridge: Cambridge University Press.

Agarwal, Anjali. 2008. "Role of NGOs in the Protection of Environment." Journal of Environmental Research and Development 2(4): 933-938.

Akella, Anita Sudari and Allan Crawford. 2012. "Wildlife Crime: Executive Summary." World Wildlife Fund, Washington DC.

https://blogs.haaretz.co.il/zafrirrinat/files/2012/12/Dismantling-Wildlife-Crime1.pdf

Akella, Anita Sudari and James, Cannon, 2004. "Strengthening the Weakest Links Strategies for Improving the Enforcement of Environmental Laws Globally" 
Alter, Karen. 2011. "The Evolving International Judiciary.” Annual Review of Law and Social Science 7(1): 387-415.

Alter, Karen J. 2014. The New Terrain of International Law: Courts, Politics, Rights. Princeton: Princeton University Press.

Alter, Karen and Raustiala, Kal. 2018. "The Rise of International Regime Complexity." Annual Review of Law and Social Sciences, UCLA School of Law, Northwestern Public Law Research Paper No. 17-30.

Ardia, David. 1998. "Does the Emperor Have No Clothes? Enforcement of International Laws Protecting the Marine Environment.” Michigan Journal of International Law 19: 497567.

Ayling, Julie. 2013. "Harnessing Third Parties for Transnational Environmental Crime Prevention." Transnational Environmental Law 2: 339-362

Avant, Deborah. 2005. The Market for Force: The Consequences of Privatizing Security. Cambridge University Press.

Avant, Deborah, Martha Finnemore, and Susan K. Sell (Eds). 2010. Who Governs the Globe? Cambridge University Press. 
Ayres, Ian and John Braithwaite. 1991. "Tripartism: Regulatory Capture and Empowerment.” Law and Social Inquiry 16 (3): 435-496.

Bayley, David H. and Clifford D. Shearing. 2001. "The New Structure of Policing:

Description, Conceptualization, and Research Agenda.” Research Report. U.S. Department of Justice. https://www.ncjrs.gov/pdffiles 1/nij/187083.pdf

Betsill, M.M. 2014. "Transnational Actors in International Environmental Politics.” 185210. In Betsill M.M., Hochstetler K., Stevis D., eds. Advances in International Environmental Politics. London: Palgrave.

Betts, Alexander. 2013. "Regime Complexity and International Organizations: UNHCR as a Challenged Institution.” Global Governance 19: 69-81.

Bob, Clifford. 2005. The Marketing of Rebellion: Insurgents, Media, and International Activism. New York: Cambridge University Press.

Breitmeier, Helmut and Volker Rittberger. 2000. "Environmental NGOS in an Emerging Global Civil Society." in Chasek, Pamela, ed. The Global Environment in the $21^{\text {st }}$ Century. UN University Press, chapter 8.

Brenner, Susan. 2007. "Private-Public Sector Cooperation in Combating Cybercrime: In Search of a Model.” Journal of International Commercial Law and Technology 2(2): 58-67 
Burbank, Stephen, Sean Farhang and Herbert Kritzer. 2013. "Private Enforcement.” Lewis and Clark Law Review 17(3): 637-722.

Buthe, Tim and Walter Mattli. 2011. The New Global Rulers: The Privatization of Regulation in the World Economy. Princeton: Princeton University Press.

Buthe, Tim. 2012 "Beyond Supply and Demand: A Political-Economic Conceptual Model." In Kevin Davis, Angelina Fisher, Bennedict Kingsbury and Sally Merry (Eds) Governance by Indicators: Global Power through Quantification and Rankings. Oxford University Press, pp.29-51.

Buxbaum, Hannah L. 2019. "Extraterritoriality in the Public and Private Enforcement of US Regulatory Law.” Indiana University, Legal Studies Research Papers 408.

Clagett, Brice M. 1996. "Title III of the Helms-Burton Act is Consistent with International Law." American Journal of International Law 90(3): 434-440.

Clark, Anne-Marie. 2001. Diplomacy of Conscience. Amnesty International and Changing Human Rights Norms. Princeton University Press.

Dancy, Geoff and Verónica Michel. 2016. "Human Rights Enforcement for Below: Private Actors and Prosecutorial Momentum in Latin America and Europe." International Studies Quarterly 60(1): 173-188. 
Daniel, Tim and James Maton. 2008. "Civil Proceedings to Recover Corruptly Acquired Assets of Public Officials." In Mark Pieth (Ed.) Recovering Stolen Assets (Bern: Peter Lang), 243-266.

Dai, Xinyuan. 2002. "Information Systems in Treaty Regimes.” World Politics 54(4): 405436.

de Sadeleer, Nicolas, Gerhard Roller, and Miriam Dross. 2002. “Access to Justice in Environmental Matters". V.A.3/ETU/2002/0030 Final Report

Doak, Jonathan. 2008. Victims'Rights, Human Rights and Criminal Justice: Reconceiving the Role of Third Parties. London: Hart.

Edmonds, Tamlyn and David Jugnarian. 2016. "Private Prosecution: A Potential Anticorruption Tool in English Law." New York: Open Society Foundations. https://www.opensocietyfoundations.org/sites/default/files/legal-remedies-4-edmondsjugnarain-20160504_0.pdf

Efrat, Asif and Abraham Newman. 2019. "Intolerant justice: ethnocentrism and transnational litigation networks". The Review of International Organizations (online first, Jan).

Eilstrup-Sangiovanni, Mette and Teale Phelps-Bondaroff. 2014. "From Advocacy to Confrontation. Direct Enforcement by Environmental NGO.” International Studies Quarterly 58(2): 348-61. 
Eilstrup-Sangiovanni, Mette. 2018. "Hierarchy among NGOs: Authority and influence in global civil society." International Politics Reviews 6(2): 99-103.

Eilstrup-Sangiovanni, Mette. 2019. “Competition and Strategic Differentiation Among Transnational Advocacy Groups”. Interest Groups and Advocacy (May 27 online).

Fine, Janice. 2017. "Enforcing Labor Standards in Partnership with Civil Society: Can CoEnforcement Succeed where the State Alone has Failed?" Politics and Society 45(3): 359-388.

Finnemore, Martha and Kathryn Sikkink. 1998. "International Norm Dynamics and Political Change.” International Organizations 52(4): 887-919.

Fisman, Ray and Miriam Golden. 2017. Corruption: What Everyone Needs to Know. Oxford: Oxford University Press.

Gallagher, Janice. 2017. "The Last Mile Problem: Activists, Advocates, and the Struggle for Justice in Domestic Courts.” Comparative Political Studies 50(12): 1666-1698.

Gemmill, Barbara and Abimbola Bamidele-Izu. 2002. "The Role of NGOs and Civil Society in Global Environmental Governance". In Global Environmental Governance: Options and Opportunities, ed. D.C.Esty and M.H. Ivanova, 1-24. New Haven: Yale Center for Environmental Law and Policy.

Gerring, John. 2012. “Mere Description.” British Journal of Political Science 42(4): 721-746. 
Gerring, John. 2017. Case Study Research: Principles and Practices. Cambridge University Press.

Gilbert, Jo-Anne and J.C.Sharman. 2016. "Turning a Blind Eye to Bribery: Explaining Failures to Comply with the International Anti-Corruption Regime.” Political Studies 64(1): 74-89.

Global Witness. 2009. Undue Diligence: How Banks do Business with Corrupt Regimes. London.

Gonzalez-Ocantos, Ezequiel. 2014. "Persuade them or Oust Them: Crafting Judicial Change and Transitional Justice is Argentina." Comparative Politics 46(4): 479-498.

Green, Jessica.. 2010. "Delegation and Accountability in the Clean Development Mechanism: The New Authority of Non-state Actors." Journal of International Law and International Relations 4(3): 21-55.

Gwynn, María Antonia. 2018. "Legal developments in the enforcement of international environmental commitments.” Global Economic Governance (GEG) Working Paper, No. 138, University of Oxford.

Hafner-Burton, Emilie. 2008. "Sticks and Stones: Naming and Shaming the Human Rights Enforcement Problem." International Organization 62(4): 689-716. 
Hampton, Matthew. 2005. “The Fourth 'R': Sustaining the ADA's Private 'Right' of Action against States for Disability Discrimination in Public Education." Washington University Law Review 83(2): 631-655.

Harrison, James. 2014. Significant International Environmental Law Cases: 2012-14.” Journal of Environmental Law 26(3): 519-540.

Hillebrecht. Courtney. 2009. "Rethinking Compliance: The Challenges and Prospects of Measuring Compliance with International Human Rights Tribunals.” Journal of Human Rights Practice 1(3): 362-379.

Johnson, Tana. 2016. "Co-operation, Co-optation, Competition, Conflict: International Bureaucracies and NGOs in an Interdependent World." Review of International Political Economy 23(5): 737-767

Keck, Margaret and Kathryn Sikkink. 1998. Activists Beyond Borders: Advocacy Networks in International Politics. Ithaca: Cornell University Press.

Khagram, S., Riker. J.V., and Sikkink, K., 2002. Restructuring World Politics: Transnational Social Movements, Networks, and Norms. Minneapolis: University of Minnesota Press.

Krahmann, Elke. 2010. Citizens, States, and the Privatization of Security. Cambridge: Cambridge University Press. 
Mahoney, James. 2015. “Process Tracing and Historical Explanation.” Security Studies 24(2): 200-218.

Martin, Lisa. 2012. “Against Compliance.” Jeffrey L. Dunoff and Mark A. Pollack (Eds) Interdisciplinary Perspectives on International Law and International Relations. Cambridge: Cambridge University Press, pp.591-610.

McCormick, John. 2011. "The Role of Environmental NGOs in International Regimes." Regina Axelrod, Stacy VanDeveer and David Downie (Eds), The Global Environment: Institutions, Law, and Policy. Third Edition. Washington: CQ Press, 92-110.

McCoy, Jennifer and Heather Heckel. 2001. "The Emergence of a Global Anti-Corruption Norm." International Politics 38(1): 65-90.

Meier, Oliver and Clare Tenner. 2001. "Non-governmental Monitoring of International Agreements." in Trevor Findlay and Oliver Meier (Eds). Verification Yearbook 2001, VERTIC, 206-227.

Messick, Richard. 2016. "Legal Remedies for Victims of Bribery under US Law.” Open Society Foundations, New York.

https://www.opensocietyfoundations.org/sites/default/files/legal-remedies-5-messick20160601 1.pdf

Michel, Veronica and Kathryn Sikkink. 2013. "Human Rights Prosecutions and the Participation Rights of Victims in Latin America." Law and Society Review 47 (4): 873-907. 
Michel, Veronica. 2018. Prosecutorial Accountability and Victims' Rights in Latin America. Cambridge: Cambridge University Press.

Milman, Oliver, "Captain deliberately sank illegal fishing vessel, claim Sea Shepherd rescuers." Guardian 7-04-2015.

Mitchell, Ronald. 2017. International Environmental Agreements Database.

https://iea.uoregon.edu/sites/iea1.uoregon.edu/files/MEAs-1857-2016.jpg

Moerloose, Benedict. 2016. "Challenging the Pillage Process: Argor-Heraeus and Gold from Ituri.” Open Society Foundations, New York.

https://www.opensocietyfoundations.org/sites/default/files/legal-remedies-10demoerloose\%20-20161107.pdf

Moffa, Anthony. 2012. "Two Competing Models of Activism, One Goal: A Case Study of Anti-Whaling Campaigns in the Southern Ocean." Yale Journal of International Law 37: 201-214.

Moyn, Samuel. 2010. The Last Utopia: Human Rights in History. Cambridge,MA: Harvard University Press.

Murdie, Amanda and David Davis 2012. "Shaming and Blaming: Using Events Data to Assess the Impact of Human Rights INGOs.” International Studies Quarterly 56(1): 1-16.

Nurse, Angus. 2013. "Privatizing the Green Police: The Role of NGOs in Wildlife Law Enforcement." Crime, Law and Social Change 59(2): 305-318. 
Obermayer, Bastian and Frederik Obermaier. 2016. The Panama Papers: Breaking the Story of How the Rich and Powerful Hide their Money. New York: OneWorld.

Oliver, Kenneth. 2011 ““Excellent’ I cried. 'Elementary!’ said He. Mutual Legal Assistance and the Present Challenges faced by the Legal Community in the Never-Ending Quest for the Recovery of Stolen Assets." In Daniel Thelesklaf and Pedro Gomes Pereira (Eds) Non-State Actors and Asset Recovery (Bern: Peter Lang), 160-182.

Parliamentary Submission by Global Witness Committee on Culture, Media and Sport on Libel and Defamation January 2009 https://publications.parliament.uk/pa/cm200809/cmselect/cmcumeds/memo/press/ucps1302.h tm.

Perdriel-Vaissiere, Maud. 2011. "How to Turn Article 51 into Reality." In Non-State Actors and Asset Recovery edited by Daniel Thelesklaf and Pedro Gomes Pereira. Bern: Peter Lang, 17-37.

Perdriel-Vaissiere, Maud. 2017. "France's Bien Mal Acquis Affair: Lesson from a Decade of Legal Struggle.” New York: Open Society Foundations.

https://www.opensocietyfoundations.org/sites/default/files/legal-remedies-11-perdriel20170612.pdf

Price, Richard. 2003. "Transnational Civil Society and Advocacy in World Politics." World Politics 55(2): 579-606.

Preston, Brian. 2016. "The Role of Courts in Facilitating Climate Change Adaptation." AsiaPacific Centre for Climate Change Adaptation.

https://papers.ssrn.com/sol3/papers.cfm?abstract_id=2829287.

Quintanilla, M.S. and C.A. Whytock. 2012. 'The new multipolarity in transnational litigation: Foreign courts, foreign judgments and foreign law." Southwestern Journal of International Law 18, 31-49.

Raustiala, Kal. 1997. "States, NGOs and International Environmental Institutions." 
International Studies Quarterly 41, 719-740.

Raustiala, Kal and Anne-Marie Slaughter. 2002. "International Law, International Relations and Compliance." In Handbook of International Relations edited by Walter Carlsnaes, Thomas Risse and Beth Simmons, Sage, Thousand Oaks CA, pp. 538-558.

Rebasti, Emmanuele and Luisa Vierucchi. 2002. "A Legal Status for NGOs in Contemporary International Law?" European University Institute. http://www.esilsedi.org/english/pdf/VierucciRebasti.PDF

Rothwell, Donald. 2013. "The Antarctic Whaling Case: Litigation in the International Court and the Role Played by NGOs". The Polar Journal 3(2): 399-414.

Ryngaert, Cedric. 2013. "Tort Litigation in Respect of Overseas Violations of Environmental Law Committed by Corporations". McGill International Journal of Sustainable Development Law and Policy 8(2): 245-260.

Sanz, Muria Garcia and Manuel Sese. 2013. "Political Corruption and Human Rights in Equatorial Guinea." In Emerging Trends in Asset Recovery edited by Gretta Fenner Zinkernagel, Charles Monteith, and Pedro Gomez Pereira. Bern: Peter Lang, 295-302.

Sending, Ole Jacob and Iver B. Neumann. 2006. "Governance to Governmentality; Analyzing NGOs, States, and Power.” International Studies Quarterly 50(3): 651-672.

Sentry. 2016. War Crimes Shouldn't Pay: Stopping the Looting and Destruction in South Sudan.

https://cdn.thesentry.org/wp-content/uploads/2016/09/Sentry_WCSP_Finalx.pdf

Sharman, J.C. 2017. The Despot's Guide to Wealth Management: On the International Campaign against Grand Corruption. Ithaca: Cornell University Press.

Shelton, Dinah. 1994. "The Participation of Nongovernmental Organizations in International Judicial Proceedings, American Journal of International Law 88: 611. 
Sikkink, Kathryn. 2002. "Transnational Advocacy Networks and the Social Construction of Legal Rule”. In Yves Dezalay and Bryant Garth (Eds.), Global Prescriptions: The Production, Exportation, and Importation of a New Legal Orthodoxy. Ann Arbor: University of Michigan Press, pp. 37-64.

Sikkink, Katrhyn. 2011. The Justice Cascade: How Human Rights Prosecutions Are Changing World Politics. New York: W.W. Norton and Company, 2011

Simmons, Beth 2010. "Treaty Compliance and Violation.” Annual Review of Political Science 13(1): 273-296.

Simmons, Beth, Paulette Lloyd, and Brandon Stewart. 2018. "The Global Diffusion of Law: Transnational Crime and the Case of Human Trafficking." International Organization 72(2): 249-281.

Singer, Peter. 2003. Corporate Warriors: The Rise of the Privatized Military Industry. Ithaca: Cornell University Press.

Stephenson, Matthew. 2016. "Standing Doctrine and Anticorruption Litigation: A Survey." New York: Open Society Foundations.

https://www.opensocietyfoundations.org/sites/default/files/legal-remedies-2-20160202.pdf

Stolen Asset Recovery Initiative (StAR). 2010. Barriers to Asset Recovery: An Analysis of Key Barriers and Recommendations for Action. Washington DC: World Bank/UN Office on Drugs and Crime.

Stolen Asset Recovery Initiative (StAR). 2014. Few and Far: The Hard Facts on Stolen Asset Recovery. Washington DC: World Bank/United Nations Office on Drugs and Crime.

Stroup, Sarah and Wendy Wong. 2017. The Authority Trap: Strategic Choices of International NGOs. Ithaca: Cornell University Press.

Tallberg, Jonas. 2015. “Orchestrating Enforcement: International Organizations Mobilizing Compliance Communities.” In Kenneth Abbott, Philipp Genschel, Duncan Snidal and 
Bernhard Zangl (Eds) International Organizations as Orchestrators. Cambridge University Press. pp.166-188.

Tallberg, Jonas, Lisa Dellmuth, Hans Agné, and Andreas Duit. 2018. "NGO Influence in International Organizations: Information, Access and Exchange.” British Journal of Political Science 48(1): 213-238.

Thelesklaf, Daniel and Pedro G.Pereira (Eds). 2011. Non-state Actors in Asset Recovery. Berne: Peter Lang.

Transparency International-UK. 2015. "Empowering the UK to Recover Corrupt Assets." London.

https://www.transparency.org.uk/publications/empowering-the-uk-to-recover-corrupt-assets/

Tseming Yang and Robert Percival. 2009. "The Emergence of Global Environmental Law." Ecology Law Quarterly 36: 615.

Tsingou, Eleni. 2019. Masters of Compliance in Money Laundering Governance. Cheltenham: Edward Elgar.

Urbina, Ian. 2015. “A Renegade Trawler, Hunted for 10,000 miles by Vigilantes.” New York Times, July 28, 2015. https:/www.nytimes.com/2015/07/28/world/a-renegade-trawlerhunted-for-10000-miles-by-vigilantes.html?_r=0

Vidal, John. 2010. "Sea Shepherd Activists Free Hundreds of Threatened Bluefin Tuna Off Libya. Guardian, June 18. http://www.guardian.co.uk/environment/2010/jun/18/seashepherd-release-bluefin-tuna-libya

Von Stein, Jana. 2010. "International Law: Understanding Compliance and Enforcement." International Studies Association Compendium Project. pp.1-18.

Wils, Wouter. 2017. "Private Enforcement of EU Anti-trust Law and its Relationship with Public Enforcement: Past, Present and Future.” World Competition 40(1): 3-46. 
Yang, Tseming. 2006. "International Treaty Enforcement as a Public Good: Institutional Deterrent Sanctions in International Environmental Agreements." Michigan Journal of International Law 27:1131-1184.

Zarate, Juan. 2013. Treasury's War: The Unleashing of a New Era of Financial Warfare. New York: Public Affairs. 


\section{Appendix}

\section{DATA \& CODING CRITERIA}

Table 1 contains a list of transnational environmental conservation NGOs ordered by founding year. Table 2 contains a similar list of NGOs working to combat corruption and money-laundering. To be included, an NGO must operate at a global level, be currently active and have a functioning website. In order to present as complete as possible a picture of the overall NGO population in these two areas, we have used searches of the Yearbook of International Organization in combination with web-links between NGOs, Facebook profiles, Linked-in pages as well as secondary academic literature. Each table indicates the main 'strategic profiles' of individual NGOs in order to illustrate the extent to which NGOs are presently engaged in enforcement.

Table 1: INGOs Working on Environmental Conservation, 1895-2018 (by founding year)

\begin{tabular}{|c|c|c|c|c|c|}
\hline & Organisation name & $\begin{array}{l}\text { Founding } \\
\text { year }\end{array}$ & Strategies & $\begin{array}{c}\text { Engages in } \\
\text { Enforcement }\end{array}$ & $\begin{array}{l}\text { Has } \\
\text { enforcement } \\
\text { as its main } \\
\text { focus }\end{array}$ \\
\hline 1 & Friends of Nature & 1895 & $\mathrm{CPC}, \mathrm{A}$ & & \\
\hline 2 & Wildlife Conservation Society & 1895 & R, EDU, GOVT & & \\
\hline 3 & Fauna and Flora International & 1903 & COR, EDU, L & & \\
\hline 4 & International Tree Foundation & 1924 & $\mathrm{CPB}, \mathrm{A}, \mathrm{L}, \mathrm{R}, \mathrm{PCP}$ & & \\
\hline 5 & Wetlands International & 1937 & $\begin{array}{l}\text { R, PCP, L, GOVT. } \\
\text { COR }\end{array}$ & & \\
\hline 6 & The Nature Conservancy & 1951 & R, CPR, GOVT & & \\
\hline 7 & Frankfurt Zoological Society & 1958 & EDU, CPC, L & & \\
\hline 8 & World Wide Fund for Nature & 1961 & R, L, COR, GOVT, IO & & \\
\hline 9 & Environ. Defence Fund & 1967 & L, LAW, R, COR, & $\mathrm{x}$ & $\mathrm{x}$ \\
\hline 10 & Friends of the Earth & 1969 & L, LAW, LI, R, A & $\mathrm{x}$ & \\
\hline 11 & Greenpeace & 1969 & $\mathrm{P}, \mathrm{L}, \mathrm{LI}, \mathrm{A}, \mathrm{PR}, \mathrm{SMC}$ & $\mathrm{x}$ & \\
\hline 12 & $\begin{array}{l}\text { International Fund for Animal } \\
\text { Welfare }\end{array}$ & 1969 & A, L, PCP, EDU, PR & & \\
\hline 13 & $\begin{array}{l}\text { Natural Resources Defence } \\
\text { Council }\end{array}$ & 1970 & $\mathrm{~L}, \mathrm{R}, \mathrm{LI}$ & $x$ & \\
\hline 14 & Earthwatch Institute & 1971 & $\mathrm{R}, \mathrm{COR}$ & & \\
\hline 15 & The Mountain Institute & 1972 & $\mathrm{~L}, \mathrm{R}, \mathrm{CP}, \mathrm{PCP}$ & & \\
\hline 16 & $\begin{array}{l}\text { International Primate Protection } \\
\text { League }\end{array}$ & 1973 & $\mathrm{~A}, \mathrm{MON} / \mathrm{ENF}, \mathrm{P}, \mathrm{PCP}$ & $\mathrm{x}$ & \\
\hline 17 & Biodiversity International & 1974 & R, EDU, PP & & \\
\hline 18 & WILD Foundation & 1974 & PR, R, GOVT, COR & & \\
\hline 19 & Worldwatch Institute & 1974 & $\mathrm{R}, \mathrm{A}, \mathrm{PR}$ & & \\
\hline 20 & Cetacean Society Intl. & 1974 & EDU, R, PE, P & & \\
\hline 21 & Earth Trust & 1974 & MON/ENF & $\mathrm{x}$ & \\
\hline 22 & TRAFFIC & 1976 & MON, R & & \\
\hline 23 & $\begin{array}{l}\text { Sea Shepherd's Conservation } \\
\text { Society }\end{array}$ & 1977 & DA, MON/ENF, IM & $\mathrm{x}$ & $\mathrm{x}$ \\
\hline
\end{tabular}




\begin{tabular}{|c|c|c|c|c|c|}
\hline 24 & Great Bear Foundation & 1981 & PCP, EDU, A & & \\
\hline 25 & World Resources Institute & 1982 & R, L & & \\
\hline 26 & A Rocha International & 1983 & PCP, R, EDU & & \\
\hline 27 & D. Shepherd Wildlife Foundation & 1984 & MON/ENF & $\mathrm{x}$ & \\
\hline 28 & $\begin{array}{l}\text { Environmental Investigation } \\
\text { Agency }\end{array}$ & 1984 & MON/ENF, TECH & $\mathrm{x}$ & $\mathrm{x}$ \\
\hline 29 & International Rivers & 1985 & $\mathrm{R}, \mathrm{A}, \mathrm{L}$ & & \\
\hline 30 & Rainforest Action Network & 1985 & DA, P, DIV. PR, PE & $\mathrm{x}$ & \\
\hline 31 & Conservation International & 1987 & PCP, COR, GOVT & & \\
\hline 32 & Rainforest Alliance & 1987 & CER, R, COR & & \\
\hline 33 & Whale \& Dolphin Conservation & 1987 & $\begin{array}{l}\text { EDU, A, PR, R, GOV., } \\
\text { GOV, IO }\end{array}$ & & \\
\hline 34 & Rainforest Trust & 1988 & $\mathrm{CPB}$ & & \\
\hline 35 & Rainforest Foundation Intl. & 1989 & A, EU, PR, L, MON & & \\
\hline 36 & Seeds of Survival & 1989 & $\mathrm{CPB}, \mathrm{EDU}, \mathrm{A}$ & & \\
\hline 37 & OCEANCARE & 1989 & R, A, L, EDU, GOV. & & \\
\hline 38 & Humane Society Intl. & 1991 & L, MON/ENF & $\mathrm{x}$ & \\
\hline 39 & Captain Planet Foundation & 1991 & EDU, A & & \\
\hline 40 & Ocean Futures Society & 1991 & EDU, PR, A, & & \\
\hline 41 & Orangutan Foundation Intl. & 1991 & R, EDU, RES & & \\
\hline 42 & $\begin{array}{l}\text { International Network for } \\
\text { Sustainable Energy }\end{array}$ & 1992 & A, L, CPC, R & & \\
\hline 43 & Project AWARE & 1992 & $\mathrm{PCP}, \mathrm{L}$ & & \\
\hline 44 & Forest Stewardship Council & 1993 & CER, COR & & \\
\hline 45 & Global Witness & 1993 & MON/ENF, TECH, & $\mathrm{x}$ & $\mathrm{x}$ \\
\hline 46 & Green Cross International & 1993 & L, EDU, A, GOV. & & \\
\hline 47 & Save the Elephants & 1993 & $\begin{array}{l}\text { R, MON, A, EDU, } \\
\text { CPB, TECH }\end{array}$ & & \\
\hline 48 & $\begin{array}{l}\text { International Analog Forestry } \\
\text { Network }\end{array}$ & 1996 & $\begin{array}{l}\text { CER, CP, A, GOV, } \\
\text { COR }\end{array}$ & & \\
\hline 49 & Marine Stewardship Council & 1997 & CER & & \\
\hline 50 & World Animal Network & 1997 & A, CPB, EDU, L, R & & \\
\hline 51 & $\begin{array}{l}\text { International Wildlife } \\
\text { CrimeStoppers }\end{array}$ & 1998 & ENF/MON & $\mathrm{x}$ & $\mathrm{x}$ \\
\hline 52 & $\begin{array}{l}\text { Programme for Endorsement of } \\
\text { Forest Certification }\end{array}$ & 1999 & CER, COR & & \\
\hline 53 & WildAid & 2000 & L, PR & $\mathrm{x}$ & \\
\hline 54 & Oceana & 2001 & $\mathrm{~L}, \mathrm{R}$ & & \\
\hline 55 & $\begin{array}{l}\text { Environmental Justice } \\
\text { Foundation }\end{array}$ & 2001 & DA, MON/ENF & $\mathrm{x}$ & $\mathrm{x}$ \\
\hline 56 & Go Green Initiative & 2002 & EDU & & \\
\hline 57 & Ideas for US & 2002 & EDU, CPC, R & & \\
\hline 58 & Sky Truth & 2002 & MON/ENF, TECH & $\mathrm{x}$ & $\mathrm{x}$ \\
\hline 59 & $\begin{array}{l}\text { Eco-Activists for Governance } \\
\text { and Law Enforcement }\end{array}$ & 2003 & DA, MON/ENF & $\mathrm{x}$ & $\mathrm{x}$ \\
\hline 60 & Global Footprint Network & 2003 & R, COR, GOVT & & \\
\hline 61 & Global Justice Ecology Project & 2003 & L, P, PCP, SMC, PR & $\mathrm{x}$ & \\
\hline 62 & Great Transition Initiative & 2003 & R, L, PCP, Think Tank & & \\
\hline 63 & Earthrace Conservation & 2004 & $\begin{array}{l}\text { DA, MON/ENF, } \\
\text { TECH }\end{array}$ & $\mathrm{x}$ & $\mathrm{x}$ \\
\hline 64 & Red Panda Network & 2004 & R, EDU, CPB, PCP & & \\
\hline 65 & Wildlife Direct & 2004 & LAW, MON & $\mathrm{x}$ & \\
\hline 66 & Good Planet Foundation & 2005 & PCP, EDU & & \\
\hline 67 & Plant a Tree Today Foundation & 2005 & $\begin{array}{l}\text { EDU, PCP, GOVT. } \\
\text { COR }\end{array}$ & & \\
\hline 68 & Endangered Species International & 2006 & L, PCP, R, TECH & & \\
\hline 69 & Panthera Corporation & 2006 & A, L, R, PCP & & \\
\hline 70 & Biofuelwatch & 2006 & $\mathrm{P}, \mathrm{A}, \mathrm{SMC}, \mathrm{R},(\mathrm{L})$ & & \\
\hline 71 & Wildlife Law Enforcement & 2006 & $\begin{array}{l}\text { MON/ENF, PR, } \\
\text { TECH, RES }\end{array}$ & $\mathrm{x}$ & $\mathrm{x}$ \\
\hline 72 & 350.org & 2007 & P, SMC, D, PR & & \\
\hline 73 & $\overline{\text { Global Wildlife Conservation }}$ & 2008 & PCP, R, CP, L, COR & & \\
\hline 74 & Client Earth & 2008 & LAW, LIT & $\mathrm{x}$ & $\mathrm{x}$ \\
\hline
\end{tabular}




\begin{tabular}{|c|l|c|l|c|c|}
\hline 75 & Earth Law Centre & 2008 & LAW, L, EDU, & $\mathrm{x}$ & $\mathrm{x}$ \\
\hline 76 & Let's Do It World & 2008 & A, PCP & & \\
\hline 77 & Carbon Market Watch & 2009 & R, L & \\
\hline 78 & Turtle Conservancy & 2009 & L, MON, CPB & \\
\hline 79 & Perfect World Foundation & 2010 & A, PR & \\
\hline 80 & & & DA, MON/ENF, & \\
& The Black Fish & 2010 & TECH, CPB & $\mathrm{x}$ & \\
\hline 81 & Coastal Conservation Network & 2011 & EDU, A, L, TECH & & \\
\hline 82 & Deep Green Resistance & 2011 & DA & $\mathrm{x}$ & \\
\hline 83 & Wildlife Protection Solutions & 2011 & TECH, EDU, R & $\mathrm{x}$ & \\
\hline 84 & Project Green World & 2012 & A, EDU & & \\
\hline 85 & Shadow View & 2012 & MON/ENF, TECH & $\mathrm{x}$ & \\
\hline 86 & & & MON/ENF, TECH, & & \\
\hline & Soar Ocean & 2013 & CPB & $\mathrm{x}$ & \\
\hline 87 & Centre for Development \& & & & & \\
\hline & Strategy & 2014 & Open Source Research & & \\
\hline 88 & This is My Earth (TIME) & 2015 & PCP & $\mathrm{x}$ & \\
\hline 88 & Wildlife Air Service & 2015 & MON/ENF & $\mathrm{x}$ & \\
\hline 90 & SeaScope & 2017 & MON/ENF, TECH & $\mathrm{x}$ \\
\hline
\end{tabular}

\section{Strategies Coded}

$\mathrm{A}=\mathrm{A}$ wareness raising and information-dissemination

CER $=$ Certification

$\mathrm{COR}=$ Direct cooperation with companies

$\mathrm{CPB}=$ Capacity building

DA = Direct Action/Civil Disobedience

DIV $=$ Divestment campaigns

$\mathrm{EDU}=$ Education and training

GOV $=$ Close cooperation $\mathrm{w}$. specific governments

$\mathrm{IM}=$ Independent media

$\mathrm{IO}=$ Close cooperation $\mathrm{w}$. specific international organizations

$\mathrm{L}=$ Direct lobbying of governments or international organizations

LAW = Legal advocacy or consulting

LIT $=$ Litigation

$\mathrm{MON} / \mathrm{ENF}=$ Monitoring and enforcement activities

$\mathrm{P}=$ Protests, rallies, marches, banner-hanging, etc.

$\mathrm{PCP}=$ Practical conservation projects $\mathrm{w}$. local/global stakeholders

$\mathrm{PE}=$ Petitions

$\mathrm{PR}=$ Press conferences, media advertisements

$\mathrm{R}=$ Research and scientific evidence

$\mathrm{SMC}=$ Social media campaigning

$\mathrm{TECH}=$ Development and implementation of high tech conservation/monitoring tools 
Table 2: International NGOs Working on Anti-Corruption 41

\begin{tabular}{|c|c|c|c|}
\hline Organization Name & $\begin{array}{l}\text { Founding } \\
\text { Year }\end{array}$ & $\begin{array}{l}\text { Engages in } \\
\text { Enforcement? }\end{array}$ & $\begin{array}{l}\text { Enforcement and } \\
\text { main focus? }\end{array}$ \\
\hline APDHE & 1976 & $\mathrm{x}($ since 2007$)$ & \\
\hline Anti-Corruption Foundation & 1993 & $\mathrm{x}$ & $\mathrm{x}$ \\
\hline Corner House & 1993 & $\mathrm{x}($ since 2003$)$ & \\
\hline $\begin{array}{l}\text { Transparency International (c. } 100 \text { national } \\
\text { chapters) }\end{array}$ & 1993 & & \\
\hline Transparency International-France & 1993 & $\mathrm{x}($ since 2007$)$ & \\
\hline Corruption Watch & 1997 & $\mathrm{x}$ & \\
\hline Sherpa & 2001 & $\mathrm{x}$ & $\mathrm{x}$ \\
\hline ANTICOR & 2002 & $\mathrm{x}$ & \\
\hline TRIAL International & 2002 & $\mathrm{x}$ & $\mathrm{x}$ \\
\hline Global Financial Integrity & 2002 & & \\
\hline Global Integrity & 2005 & & \\
\hline Global Witness & 2006 & $\mathrm{x}$ & $\mathrm{x}$ \\
\hline Open Society Foundations & 2009 & $\mathrm{x}$ & \\
\hline Publish What You Pay & 2011 & $\mathrm{x}$ & \\
\hline The Sentry & 2015 & $\mathrm{x}$ & $\mathrm{x}$ \\
\hline
\end{tabular}

\footnotetext{
${ }^{41}$ Because anti-corruption NGOs tend to use a different range of strategies and tactics than environmental conservation NGOs and tend to focused on enforcement to an even greater extent, we have simply noted 'main strategic profile' for these groups.
} 


\section{AUTHOR BIOS}

Mette Eilstrup-Sangiovanni is Senior Lecturer in the Department of Politics and International Studies at the University of Cambridge and Fellow of Sidney Sussex College, Cambridge. Her research focuses on international cooperation, with particular focus on institutional design and organizational ecology, international security, and transnational advocacy. Her latest articles include, "Death of International Organizations: The organizational ecology of IGOs, 18152015" (Review of International Organizations, 2018), "Competition and Strategic Differentiation Among Transnational Advocacy Groups - an ecological perspective" (Interest Groups \& Advocacy, 2019) and "Why the world needs an International Cyberwar Convention" (Philosophy \& Technology, 2019).

J.C. Sharman is Head of the Department of Politics and International Studies at the University of Cambridge, Sir Patrick Sheehy Professor of International Relations and Fellow of King's College, Cambridge. Sharman's research is focused on the regulation of global finance, especially as relates to money laundering, tax, corruption and offshore financial centres, and the international relations of the early modern world. His latest books are The Despot's Guide to Wealth Management (Cornell University Press 2017), and Empires of the Weak: The Real Story of European Expansion and the Creation of the New World Order (Princeton University Press 2019). 